\title{
Rancang Bangun Aplikasi Penyedia Layanan Jasa Fotografer Dan Videografer Berbasis Android
}

\author{
Ferdi Indra Arfiansyah ${ }^{1}$, Endang Kurniawan ${ }^{2}$ \\ Universitas Pesantren Tinggi Darul Ulum Jombang ${ }^{1}$ \\ ferdiindra0@gmail.com
}

\begin{abstract}
Abstrak - Aplikasi Penyedia Layanan Jasa Fotografer Dan Videografer Berbasis Android merupakan sebuah aplikasi yang digunakan untuk menyediakan layanan bagi para fotografer dan videografer untuk memasarkan dan mengelola jasanya.

Jasa fotografer dan videografer sering kali dibutuhkan untuk mendokumentasikan sebuah acara ataupun hal-hal yang dianggap sangat penting. Dengan aplikasi ini orang-orang akan lebih mudah menemukan jasa fotografer dan videografer. Penggunaan aplikasi ini diharapkan dapat mempermudah bagi penyedia jasa dan orang yang akan memesan untuk menentukan kapan pelayanan akan dilakukan. Aplikasi ini dirancang menggunakan UML (Unified Modelling Language) dan dibuat menggunakan bahasa pemrograman java android dan MySQL untuk mengolah database, yang mana aplikasi ini diharapkan dapat membantu dan mempermudah pihak yang bersangkutan.
\end{abstract}

Kata kunci: Aplikasi, Fotografer, Videografer, Android, Jasa

\section{Latar Belakang}

Dokumentasi merupakan suatu proses dalam mengumpulkan data yang sistematis supaya data tersebut dapat di olah dan menghasilkan dokumen yang mana tujuan dari dokumentasi adalah untuk mendapatkan dokumen dan bukti. Dokumentasi dapat dilakukan dengan banyak cara di antaranya adalah dengan foto dan video. Foto dan video saat ini sudah berandil besar dalam dokumentasi karena dengan seiring berkembangnya zaman dan cepatnya perkembangan teknologi menjadikan dokumentasi dengan foto dan video menjadi lebih baik. Untuk mendapatkan hasil foto dan video yang maksimal dalam mendokumentasikan suatu acara tertentu dibutuhkan alat untuk menangkap momen tersebut dan juga dibutuhkan seorang yang berpengalaman dalam bidang tersebut (fotografi dan videografi) yaitu fotografer dan videografer. Pekerjaan sebagai fotografer dan videografer sudah berkembang pesat saat ini akan tetapi tidak sedikit pengguna jasa yang masih kesulitan mencari penyedia jasa tersebut karena kurangnya informasi mengenai lokasi penyedia jasa. Sering kali pengguna jasa tidak dapat memesan tepat waktu karena jadwal bertabrakan dengan pengguna jasa lain.

\section{Kajian Pustaka}

(Nugroho, 2015) dalam jurnalnya membahas tentang sistem informasi pemesanan jasa fotografi memaparkan tentang media promosi yang digunakan Karma Kreatif melalui brosur dan kartu nama sehingga memiliki keterbatasan dalam informasi yang dimuat. Selain itu untuk membuat brosur dan kartu nama membutuhkan dana cukup besar untuk percetakan dan tenaga yang digunakan untuk penyebaran brosur dan kartu nama terseut. Maka dibuat aplikasi untuk memudahkan pelanggan mendapatkan informasi yang lebih lengkap tanpa harus mendatangi workshop Office Karma Kreatif.

(Irwansyah, 2015) dalam penelitiannya menjelaskan bahwa pemesanan jasa fotografi di Banana Photography masih manual yaitu pelanggan harus datang ke tempat Banana Photography dan harus antre satu per satu untuk memesan apalagi tempat Banana Photography yang kurang strategi sehingga kurang efektif dan memerlukan waktu yang cukup lama untuk memesan terutama bagi pelanggan yang memiliki keterbatasan waktu. Maka dari itu perlu dibangun sistem dimana dapat mempermudah pelanggan dengan keterbatasan waktu untuk memesan jasa fotografi tersebut.

(Wibowo, 2016) juga menjelaskan dalam penelitiannya bahwa penyewaan pada Jn Photograph Kudus dalam bidang fotografi sering mengalami masalah diantaranya pengelolaan penjadwalan, item dan proses pemesnan yang harus dilakukan di tempat Jn Photograph Kudus. Sistem yang dikembangkan diharapkan mampu mengatasi berbagai masalah pada proses pemesanan maupun pembelian pada Jn

Rancang Bangun Aplikasi Penyedia Layanan Jasa Fotografer Dan Videografer Berbasis Android 
Photograph Kudus. Pembuatan aplikasi ini dirancang menggunakan UML dan bahasa pemrograman PHP.

(Wibisono, 2016) telah melakukan penelitian tentang portal Wedding Organizer yang mana aplikasi ini dibuat untuk membantu pasangan pengantin menemukan keperluan pernikahan seperti tempat acara, catering, perias, hiburan dan lain-lain sehingga mereka dapat mewujudkan pesta pernikahan yang diidamkan. Aplikasi ini juga membantu para penyedia jasa wedding organizer lebih mudah dikenal dan mendapat pelanggan.

(Setiawan, 2014) telah melakukan penelitian tentang Website Fotografi Berbasis Web yang mana aplikasi ini dibuat untuk membantu pelanggan melakukan order foto dan cetak foto secara online.

\section{Perancangan Sistem / Metode Penelitian}

\section{a. Analisis Sistem Yang Diusulkan}

Dalam pemesanan jasa fotografer dan videografer mungkin terjadi kendala, seperti pengguna jasa kesulitan untuk menemukan penyedia jasa dengan konsep dan harga sesuai karena kurangnya informasi tentang penyedia jasa tersebut serta jadwal pemesanan yang bertabrakan dengan pelanggan lain. Beberapa masalah tersebut akan teratasi dengan memanfaatkan aplikasi android sebagai media pemesanan online sehingga akan lebih memudahkan pengguna jasa untuk memesan karena tidak perlu datang ke lokasi penyedia jasa dan penyebaran informasi akan semakin luas, Dapat dilihat pada Gambar 1.

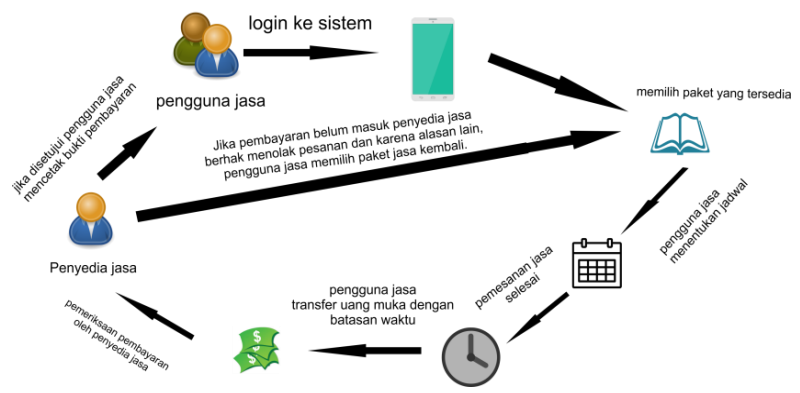

Gambar 1. Analisis Sistem Yang Diusulkan

\section{b. Pemodelan use case}

Use case diagram dalam sistem, memiliki 3 Aktor yang masing - masing mempunyai tugas :

1. Admin

Dalam sistem ini admin dapat melakukan login, logout dan mengelola user.

2. Pengguna Jasa Rancang Bangun Aplikasi Penyedia Layanan Jasa Fotografer Dan Videografer Berbasis Android
Pengguna jasa dapat melakukan login, pendaftaran, logout, melihat info jasa, memesan jasa, memberikan ulasan dan melakukan pemesanan.

3. Penyedia Jasa

Penyedia jasa dapat melakukan login, pendaftaran, logout, mengelola pembayaran, mengelola jadwal, mengelola pesanan, menerima dan menolak pemesanan

Berikut adalah tampilan dari desain use case aplikasi yang akan dijelaskan dalam gambar 2 .

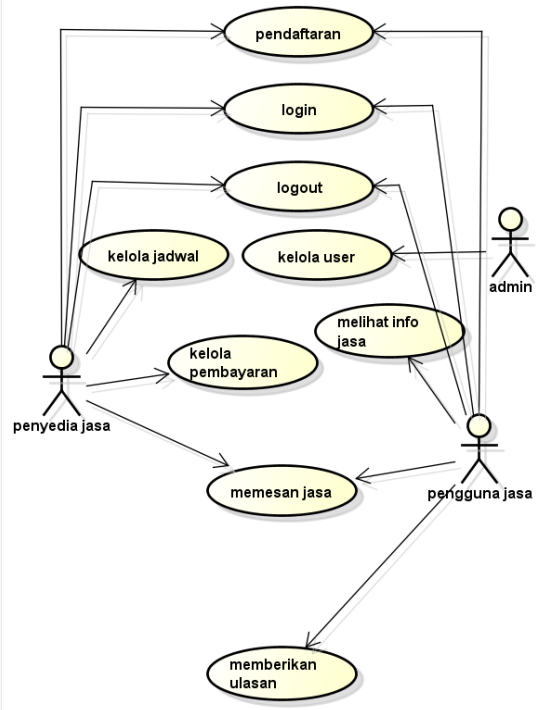

Gambar 2. Use Case Diagram

\section{Implementasi Sistem dan Hasil}

\section{a. Halaman Login}

Pada halaman ini dapat melakukan login dengan cara mengisi form email dan password. Jika data yang diisikan sesuai maka akan masuk halaman utama, Dapat dilihat pada Gambar 3.

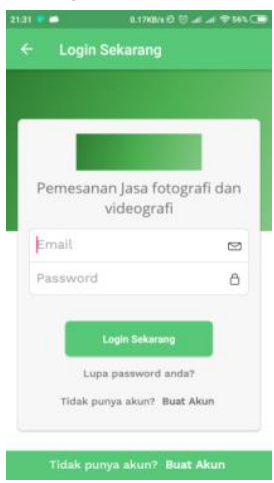

\section{b. Halaman Registrasi}

\section{Gambar 3. Halaman Login}

Pada halaman registrasi terdapat menu registrasi yang digunakan untuk mendaftar akun dengan mengisi form yang disediakan. Halaman registrasi 
bisa diakses oleh pengguna jasa dan penyedia jasa, Dapat dilihat pada Gambar 4.

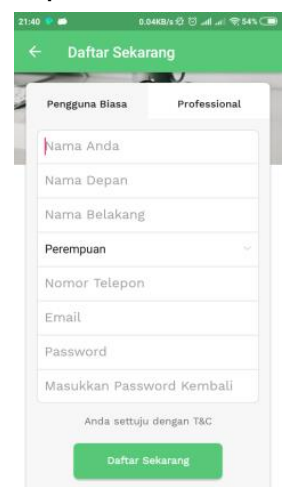

\section{Gambar 4. Halaman Registrasi}

\section{c. Halaman Utama}

Halaman utama digunakan untuk menampilkan data penyedia jasa yang tersedia dan terdapat menu pencarian penyedia jasa, Dapat dilihat pada Gambar 5.

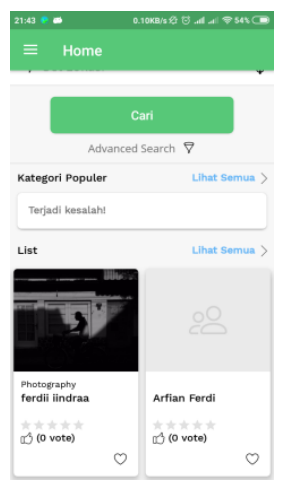

\section{Gambar 5. Halaman Utama}

\section{d. Halaman Detail Jasa}

Halaman detail jasa tampil ketika telah memilih salah satu penyedia jasa yang terdapat pada halaman utama. Halaman detail jasa digunakan untuk menampilkan informasi mengenai jasa yang disediakan, Dapat dilihat pada Gambar 6.

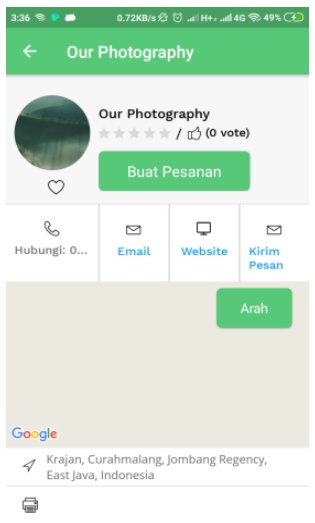

Gambar 6. Halaman Detail Jasa

\section{Kesimpulan}

Setelah melakukan perancangan dan pembangunan Aplikasi Pelayanan Jasa Fotografi dan Videografi, maka dapat diambil kesimpulan sebagai berikut:

1. Penelitian ini menghasilkan Aplikasi Penyedia Jasa Layana Fotografi dan Videografi.

2. Sistem yang dihasilkan digunakan penyedia jasa fotografi dan videografi untuk menjual jasa secara online serta untuk pengelolaan jadwal.

3. Sistem yang dihasilkan mempermudah pengguna jasa menemukan penyedia jasa fotografi dan videografi yang sesuai keinginan serta memudahkan melihat informasi jadwal dan lokasi penyedia jasa.

\section{Pustaka}

[1] Abdurahman, H., \& Riswaya, A. R. (2014). Aplikasi Pinjaman Pembayaran Secara Kredit Pada Bank Yudha Bhakti. Jurnal Computech \& Bisnis, 62.

[2] Agung, G. (2015). Mengenal Dasar-Dasar Pemrograman Android.

[3] Harahap, N. S. (2012). Pemrograman Aplikasi Mobile Smartphone dan Tablet PC Berbasis Android.

[4] Irwansyah, A. (2015). Sistem Informasi Jasa FOto pasa Banana Photography Berbasis Web.

[5] Lupiyoadi, R. (2014). Manajemen Pemasaran Jasa Berbasis Kompetensi.

Rancang Bangun Aplikasi Penyedia Layanan Jasa Fotografer Dan Videografer Berbasis Android 
[6] Mubarak, Z. Y., Noor, E., Destyanto, F., Nugroho, K. T., Mustofa, M. I., \& Arif, A. M. (2017). PERANCANGAN SISTEM INFORMASI KESEHATAN DI TINGKAT POSYANDU CILACAP SELATAN KABUPATEN CILACAP. Seminar Nasional Teknologi Informasi dan Multimedia 2017, 6.

[7] Nugroho, R. (2015). Sistem Informasi Pemesanan Jasa Fotografi Berbasis Web pada Karma Kreatif.

[8] Pratama, I. A. (2014). Sistem Informasi Dan Implementasinya. Bandung: Informatika Bandung.

[9] Segara, T. M. (2012). Akademi Dan Galeri Fotografi Yogyakarta.

[10] Setiawan, H. (2014). RANCANG BANGUN WEBSITE FOTOGRAFI ONLINE MENGGUNAKAN PHP STUDI KASUS DI COLOUR PHOTOGRAPHY.

[11] Sudarma, I. (2014). Fotografi.

[12] Wibisono, Y. P. (2016). Portal Wedding Organizer Menggunakan Sistem Informasi Geografis Berbasis Website di Kabupaten Kudus.

[13] Wibowo, A. (2016). Sistem Informasi Pengelolaan dan Penyewaan Jasa Fotografi di JN Photograph Kudus.

[14] V. (2012). Rekayasa Perangkat Lunak Berorientasi Objek. Jakarta: Penerbit Mitra Wacana Media. 